\title{
Challenge to Restore the Heritage Buildings Damaged by the 2011 Tsunami Attacks, Kesennuma, Japan
}

\author{
Hideo Izumida \\ Department of Architecture and Civil Engineering , Toyohashi University of Technology, Aichi 441-8580, Japan
}

\begin{abstract}
A large number of towns along the Sanriku coastal line were swept away by tsunami attacks on March 11, 2011. Although some heritage buildings survived, the damage condition was too severe to carry on repair and restore them to the owners. As the municipal cultural heritage division and local cultural society in Kesennuma City were looking for possibility to save these damaged heritage buildings, the author gave them full assistance. To apply for fund for the repair and restoration work to related foundations, the author made an investigation of the damage conditions, prepared measured drawings, fundamental restoration plans and cost estimates. Domestic and international foundations granted funds to our projects for three years in May 2012, and we formed a restoration body to take responsibility of repair and restoration work. But soon, we were faced with several difficulties. The first is that we had to wait for a long time until the authority fixed the town redevelopment plan, meeting the National Guideline of Tsunami-Free Redevelopment. The second is that the building cost continued to increase during rapid-development periods. Although the author expected to complete the whole work within three years, the progress is really slow, and has not amounted to a quarter.
\end{abstract}

Key words: Heritage building, repair, restoration, tsunami, disaster, Japan, timber structure.

\section{Introduction}

Earthquake has been the most common disaster in Japan, so, Japanese people have taken a series of measures to protect human life and social infrastructure by upgrading earthquake-proof structural performance. However, the offshore earthquake sometimes triggers the Tsunami (giant wave), which have thoroughly destroyed both natural and built environment of coastal area. Sanriku, a coastal area of North Eastern Japan has been attacked by several tsunamis in the last two centuries: the Meiji-Sanriku Tsunami in 1896, the Shouwa-Sanriku Tsunami in 1933, and the Tohoku-Pacific Offshore Earthquake and Tsunami in 2011 [1]. The latest one took nearly 20,000 persons and destroyed numerous buildings.

Japanese people had no power against the tsunami attacks, but their ancestor warned and gave them a

Corresponding author: Hideo Izumida, Dr., research fields: architectural history and heritage restoration. E-mail: izumida@ace.tut.ac.jp. very important oral tradition: "Living along coastal line was very risky, and once sensed the sign of tsunami, leave costal line for highland quickly." However, after the Shouwa-Sanriku Tsunami (1933), several villages and towns moved to highlands and a breakwater was constructed at the mouth of a bay with official subsidy. Six months after the last tsunami (2011), Japanese government launched a Guideline for Overall Tsunami-free Redevelopment [2], which gives options to the community and people to move to highland or stay at the same town under the protection of tall breakwater and land raisings. Then, affected municipalities get started to prepare the redevelopment scheme through discussing details of the scheme with interested parties, and examining various effects of the scheme.

Kesennuma City, one of the major cities along the Sanriku coastal line, lost its historical built-up area by the tsunami attacks, leaving several severely damaged heritage buildings on the site. People are struggling to restore their economic and living base as well as their 
cultural identity at the same town.

The general object is to report the project progress and problems of the restoration projects of the heritage buildings, all damaged by the tsunami of 2011 by analyzing people's actions for restoration and responses of authority.

\section{Kesennuma in Past Disasters}

Kesennuma town was supposedly founded in the 14th century to collect gold mined from the inland area, and ship it to Sendai, Edo (presently Tokyo) and Kyoto. The early town consisted of two areas, inland settlement and inner harbor area, or Furumachi and Naiwan. They were approx. $1 \mathrm{~km}$ away, and were connected by east-west main road. So, early settlers recognized that harbor area was not suitable for living, but just for working [3]. The Naiwan is located at an end of long bay from the Pacific Ocean, and safe from ordinary natural disasters such as typhoon, billow and storm (Fig. 1).

The Naiwan, however, was reclaimed and developed for fishery and food industry in modern period, then was soon built up by shop, office, factory, eating and drinking place and houses. As the town prospers, rice-wine brewery industry was also developed at north hillside, namely Kakuboshi Brewery and Otokomaya Brewery, which soon founded head office and shop along the Nairan main street.

In the last century, the city was attacked by middle scaled tsunamis in 1894 and 1931, but the damages were not severe. On the other hand, Naiwan was destroyed twice entirely by accidental fires took place in 1916 and 1929 (Fig. 2). But people could restore the town and industry with efforts and prospered again. After the 1929 Fire, people introduced fireproof construction by covering timber structure with reinforced mortar wall. Some of them just followed the previous timber building appearance, while others introduced masonry or RC (reinforced concrete)-like appearance (Fig. 3). In the 1970s, the city became one of the five biggest fishery base in Japan.

\section{Survived Heritage Buildings}

The latest tsunami was a horrible one, which is

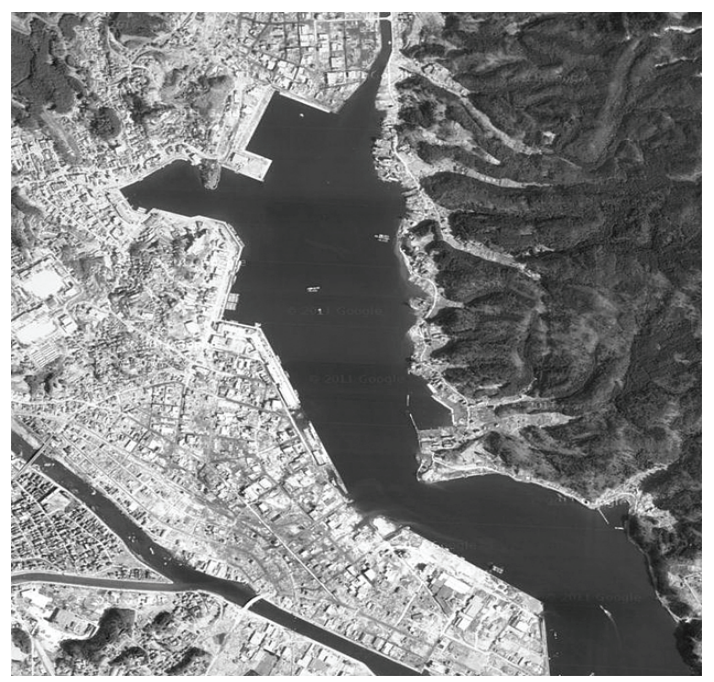

Fig. 1 Kesennuma Bay, two months after the 2011 Tsunami.

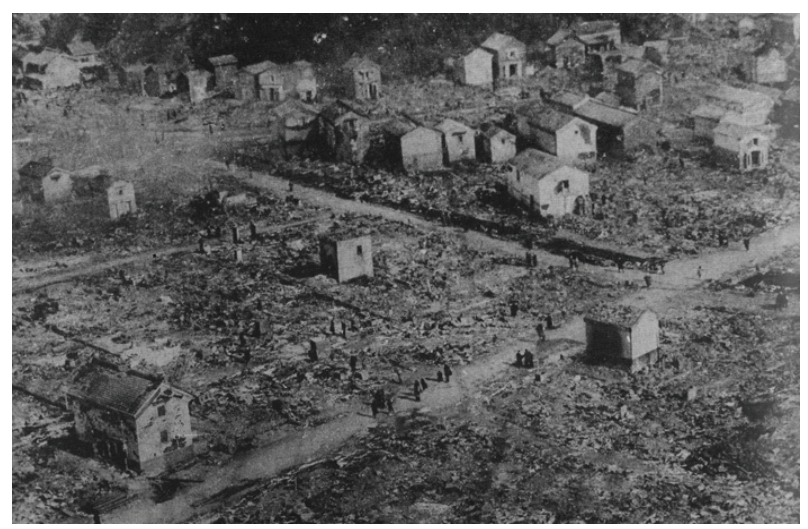

Fig. 2 Scene of Naiwan after the 1929 Fire leaving many dozos (fireproof godown) on the site.

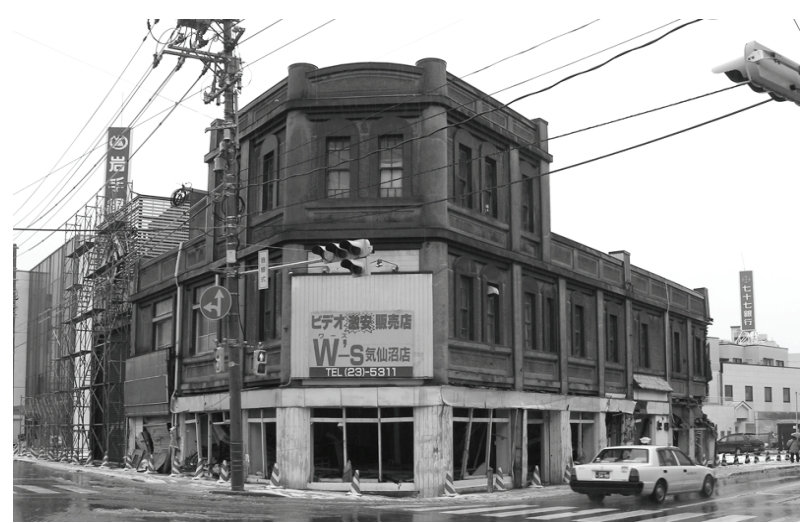

Fig. 3 RC-like timber framed + mortar wall building built after the 1929 fire. 
believed to take place once in 10 centuries. Giant waves as high as 20 30 m attacked the Sanriku coastal line, and reached Naiwan in 5 6 $\mathrm{m}$ high together with various floating objects including steel ships and building timbers. Although the reinforced concrete and steel buildings could stand the tsunami attacks, the service facility and equipment got fatal damage like car and machine soaked in seawater, and needed to be demolished for reconstruction. Of course, timber buildings were also swept away and destroyed by the tsunami attacks, but some of them survived in miserable state. They were all heritage buildings, which have been recognized by the National Listed Heritage $^{1}$ by the Agency of Cultural Affairs in 2001 (Fig. 4).

Prosperous families used to build dozo, thickly clay-plastered godown to protect their valuables from thief and fire, and they properly functioned in previous fires (Fig. 2). Although the dozo can stand tsunami attacks, it will be soaked by seawater and tends to get heavy damage. Onoken's dozo built in 1946 was washed by seawater both inside and outside (Fig. 5), and the owner hesitated to repair it because he had to restore his house and fishery facility at the same time. Moreover, it was not easy to find skilled plasterer who could make dozo work for him.

The Kakuboshi and the Otokoyama Rice-Wine Brewery both rebuilt their office and shop with timber building plastered by reinforced mortar after the 1929 Fire. The tsunami attacks took away lower floor of these buildings, and left the upper floor on the site nearby (Figs. 6 and 7). It is really mysterious why a building is broken into two parts, the lower and the upper floor. Multi-storied Japanese timber buildings have a weakness in connection of post and girder, and post tends to break by sudden lateral force. Another reason should be lack of proper lapping length of wire-laths and reinforcements (Fig. 8).

\footnotetext{
${ }^{1}$ The Registered National Assets is a category of the National Assets. The owner is responsible to maintain the original appearance, and possible to alter the interior and function without public assistance.
}

The fourth survived heritage building is the Takeyama Rice Shop, which was also built after the 1929 Fire. This timber shop house is also fireproof construction with sheet copper siding. The tsunami attacks took away its shop front, and then the second floor stayed there in critical balance (Fig. 9). As soon as the owner saw the condition, he gave immediate supports between shop floor and second floor girders, and could not help thinking to give up the building sooner or later.

\section{The Owners' Dilemma}

Onoken's dozo, Takuboshi Brewery Shop, Otokomaya Brewery Shop and Takeyama Rice Shop all are the national listed heritage, which are recognized by the Agency of Cultural Affairs, but not financially supported by the agency. The owner is responsible for preservation of the original external appearance, but can renovate the interior to give new function to the space. Therefore, the owner has to bear all cost for the maintenance of the property. During the 1990s of local identify discovering movement, Kesennuma's learned people formed a society of local cultural history and heritage, so called the Kazemachi-Kenkyukai with support of external scholars, and carried out several projects to upgrade cultural value of the city. The owners of historical houses and buildings joined this society, and successfully made their property as the national listed heritage through application to the agency. The society was going to the next stage, periodically discussing how they could integrate these cultural values with community development, and commercial and tourism development in their office, the second floor of the Kakuboshi's shop (Fig.10). After the tsunami attacks, their discussion panels and papers were scattered around on the floor, and it is really sad to see the scene of losing dream, and the author wished to do something for them.

The owners of the damaged houses and buildings had to decide to give up them or repair them by themselves 


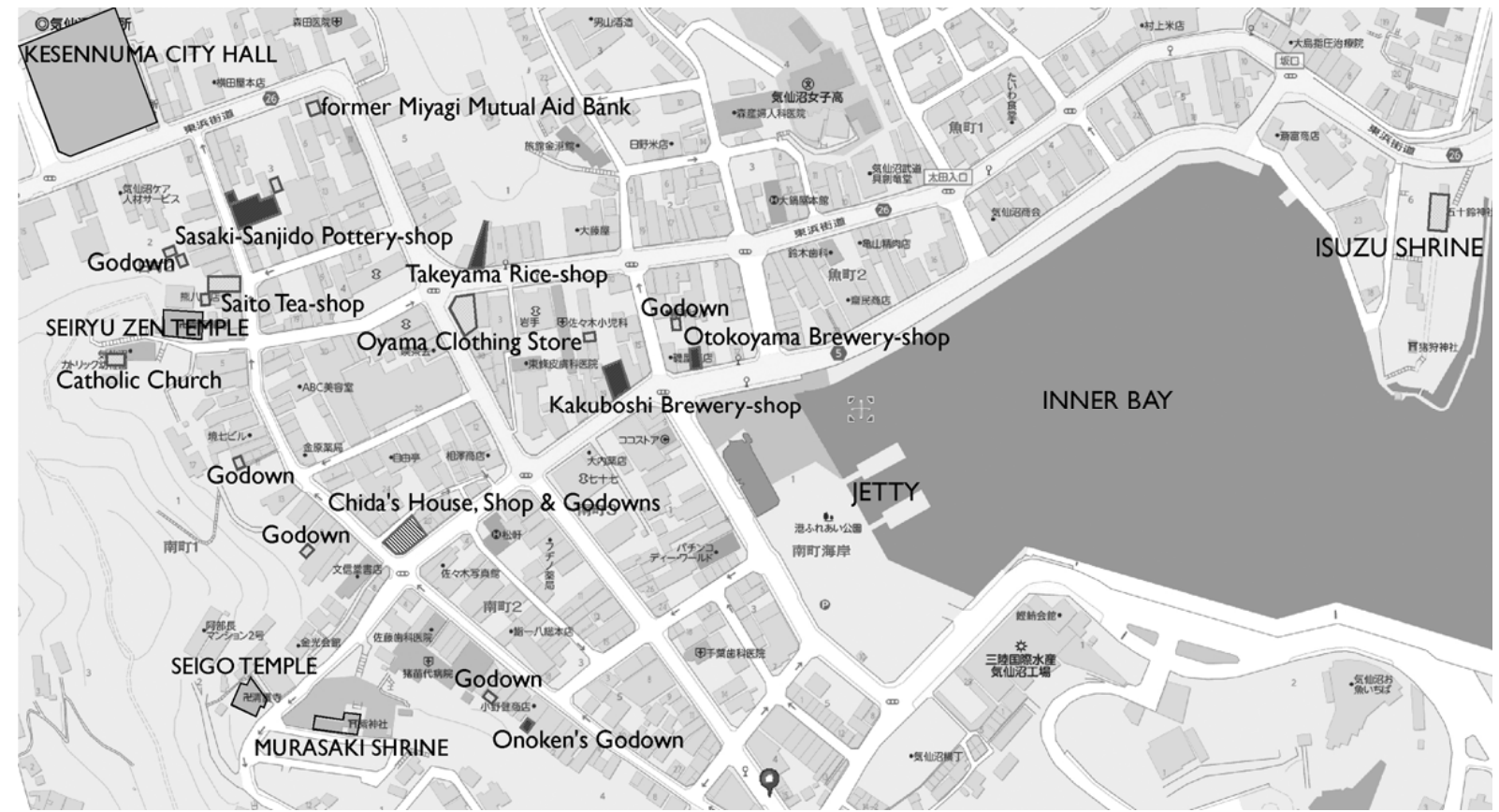

Fig. 4 Survived heritage buildings in the inner bay area.

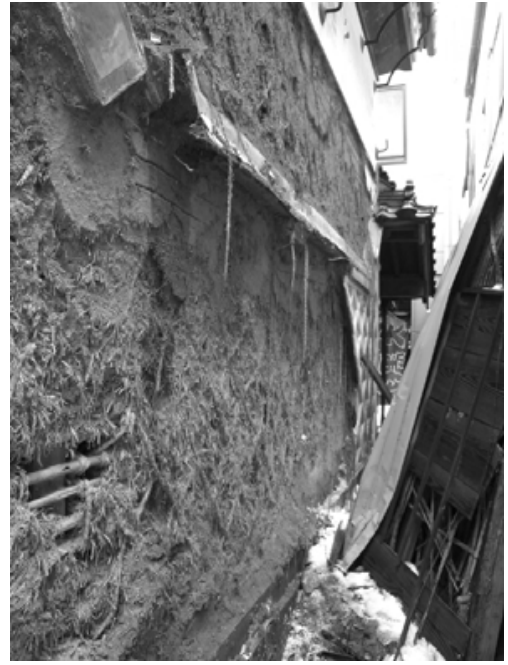

Fig. 5 Onoken's Dozo after the tsunami attacks.

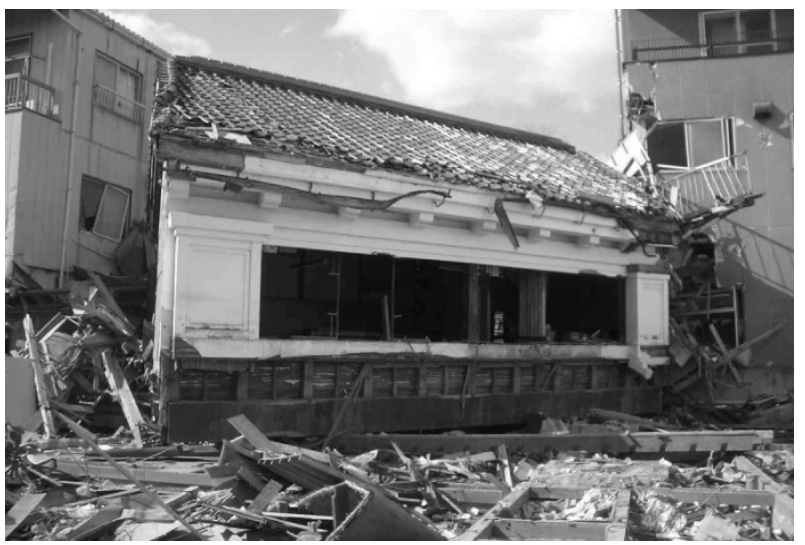

Fig. 6 Kakuboshi Brewery Shop after the tsunami attacks.

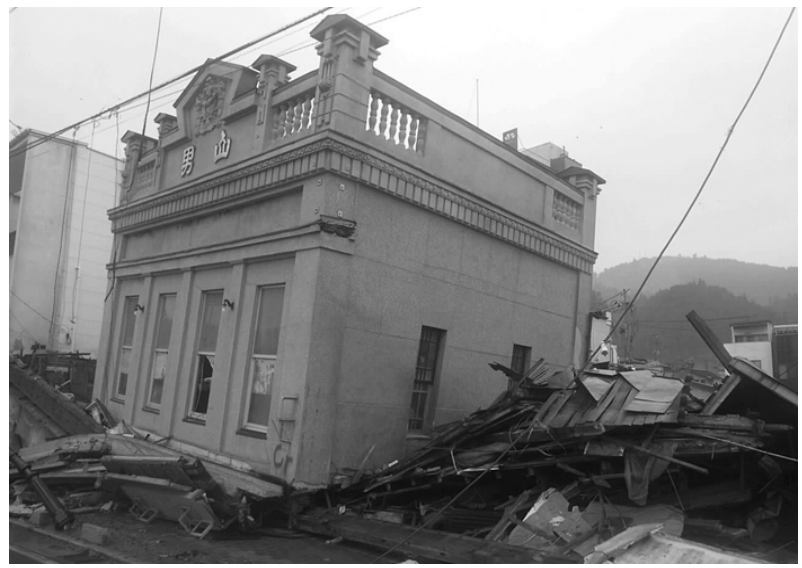

Fig. 7 Otokoyama Brewery Shop after the tsunami attacks.

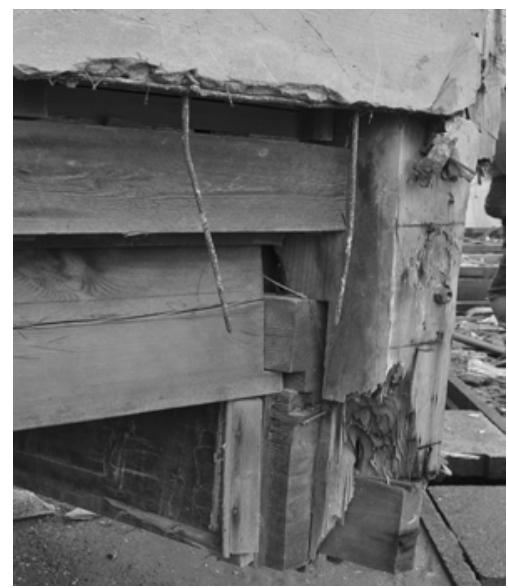

Fig. 8 Reinforced mortar wall, cut by the tsunami attacks. 


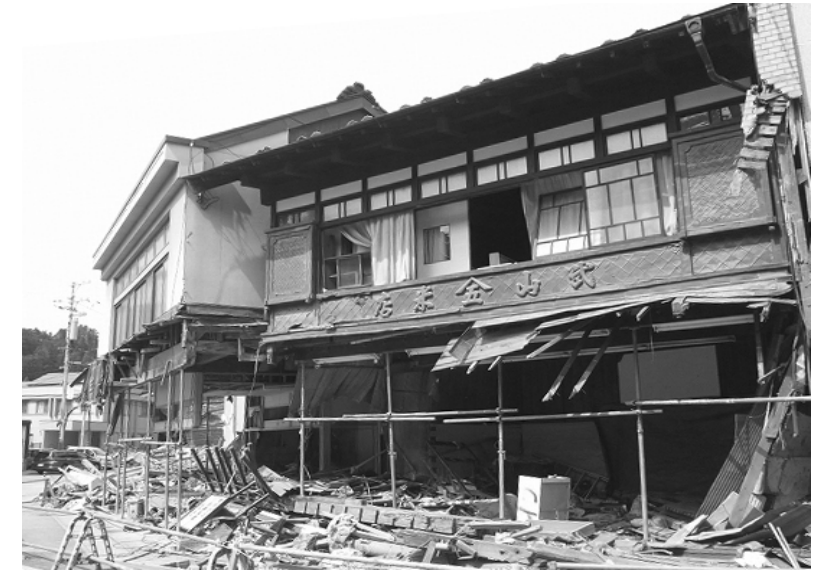

Fig. 9 Takeyama Rice Shop after the tsunami attacks.

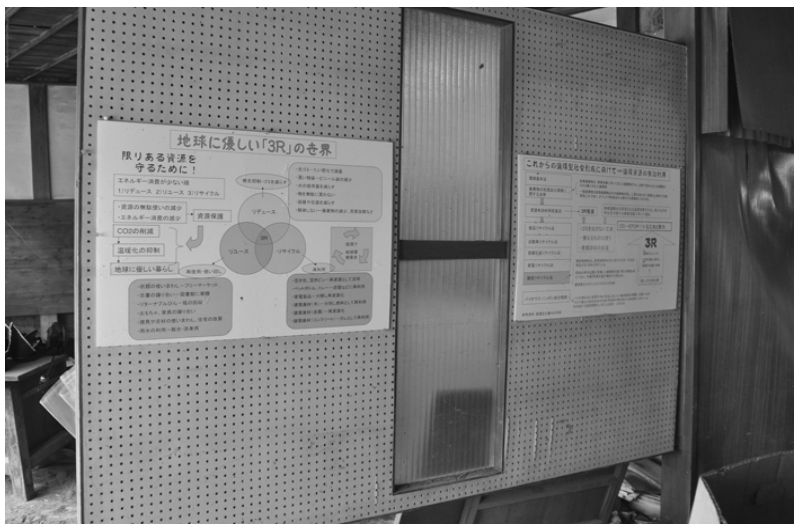

Fig. 10 Discussion panels for our future at Kakuboshi's shop.

soon, so that the authority might dismantle the property and remove them all together with other wastes by their responsibility. Overall mood of the victims was to give up their properties, and build new ones with official supports after the authority completed the infrastructure redevelopment, but the owners of these heritage buildings hesitated to do that because giving up heritage meant giving up their dream.

\section{Sympathy to Victims and the Damaged Heritage}

Several months after the tsunami attacks, officers of the Agency of Cultural Affairs together with staff of various culture-related NGOs and foundations visited the affected area to investigate the damage of heritages. Although the agency does not subsidize fund, it could direct worldwide attention to the damaged heritages. Then Japan Trust, Foundation for Cultural Heritage and Art Research, World Monuments Fund, etc. soon expressed their sympathy and assured the heritage owners of granting fund for restoration.

The heritage owners, however, could not afford to deal with any restoration work as they were so busy with reconstruction of their life and business, and still teetered whether they could go along this line or not, as most of the victims were going to give up their damaged properties and wished to restart their life with new houses and buildings. All of them experienced hardship and made critical decision. One heritage owner confessed us that he did not want to show his building of miserable condition to the public anymore, and wanted to demolish his property. We persuaded him not to do it as we would take care of all effort.

The Agency of Cultural Affairs appointed MANU Consultants Co. as a mediator among municipal cultural property division, the heritage owners and fund providers, and the author participated in this restoration programme as technical advisor in January 2012. The consultants and the author started to prepare various fund application documents including fundamental restoration plan. As applicant of the fund had to be the owner, we submitted the application to the foundations by each owner's name through city's cultural division. After the funds were granted, we formed a corporation, KFK (Kazemachi Fukkou Kentoukai) to take responsibility of the entire works (Fig. 11).

\section{Tsunami-Free Redevelopment Plan}

Soon after the tsunami attacks, the government ordered the affected municipalities to issue building control by law that prohibited any building activities in the affected area until the authority enacts new redevelopment plan and building code. As living infrastructure has been broken down, people had to move to shelter or temporary housing. The authority 


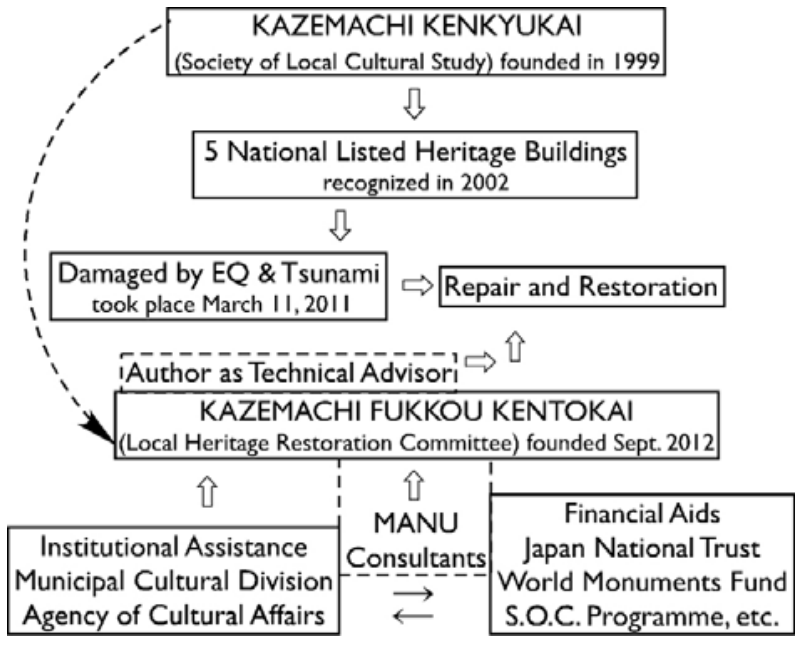

Fig. 11 Organization of repair and restoration works.

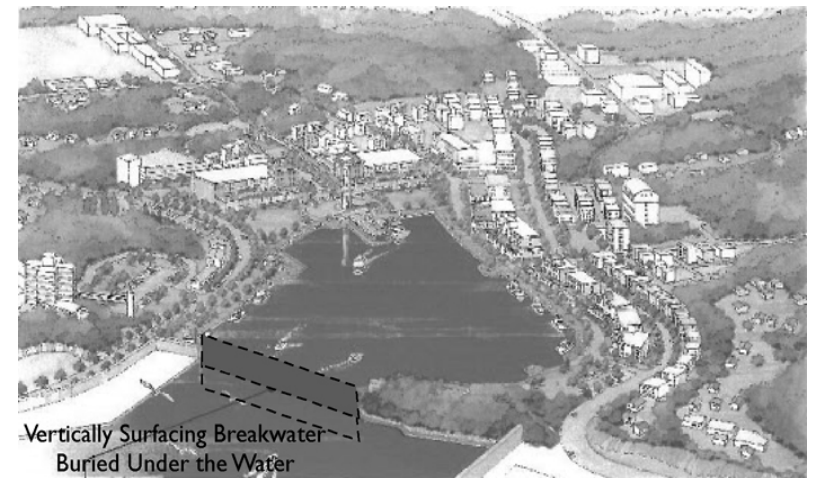

Fig. 12 First prize, surfacing breakwater for the Naiwan area.

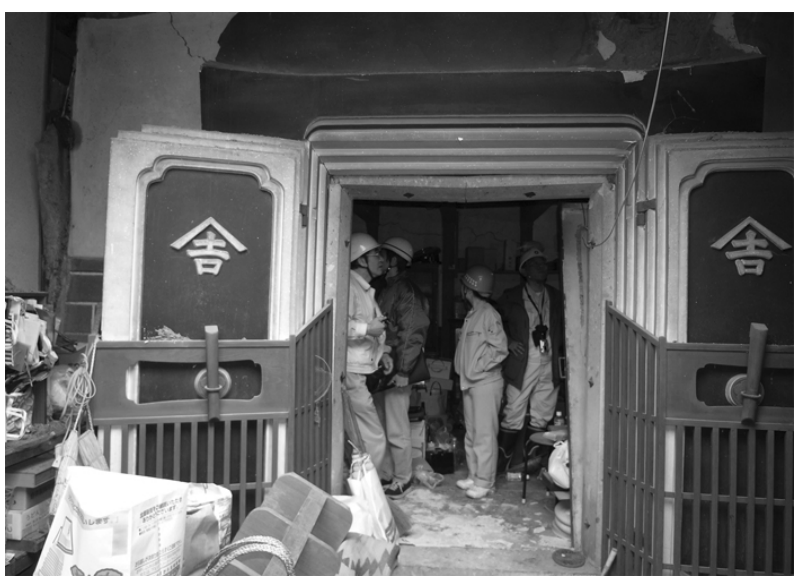

Fig. 13 Scene of survey of the damaged Dozos at Wajima, 2007.

needed to concentrate on relief of human life and support to their emergency economic activity in the first year after the tsunami, and was gradually sifting to town redevelopment project, while the central government prepared guideline for tsunami-free Town redevelopment, which consisted of breakwater construction and land raisings [4]. The authority had to fix the position of breakwater and land raising area through discussion with local community.

If the authority redevelops the town by government subsidy, they needed to meet the guideline and protect the town from L2 Level tsunami by tall breakwater, which might destroy the scenery and function of port-town. Mayor of Kesennuma City invited experts for the open competition of alternative tsunami-free redevelopment idea of the Naiwan area in February 2012 [5]. The competition committee selected an idea that would protect the area with vertically surfacing giant breakwater buried under the water of the mouth of the Naiwan among 19 applicants (Fig.12).

This idea was, however, regarded to be unreliable by leading academicians, and eventually rejected in higher political decision-makers. Therefore, the authority had to accept construction of breakwater along the harbor specified by guideline, and formed the conference to discuss the town redevelopment plan including details of breakwater and land raisings with people and party concerned. It is really a long and hard way to get an agreement among the people concerned. March 2015 will be the third year after the tsunami disaster, and we expect that the conference conclude a final redevelopment plan soon.

\section{Fundamental Restoration Plan}

The author has been involved in various restoration projects including emergency work after the disasters. In 2007, a strong earthquake hit Wajima City, and damaged numerous houses and workshops (Fig. 13).

After the 2011 earthquake and tsunami, the author visited several affected sites, and investigated damage conditions, then was looking for timing for restoration work, sending proposal letter to each affected municipality [6]. As soon as various foundations proposed to offer their fund for repair and restoration work in December 2011, the author started to make fundamental restoration plan and cost estimate for 
Kesennuma City and Kazemachi-Kenkyukai in February 2012. The works included drawing of the damaged buildings, repair and restoration planning and cost estimate with support of associating consultants, contractors, carpenters, plasterers, students, etc. (Fig. 14).

\subsection{Onoken's Dozo}

Plaster and clay wall, and ornament tiles were washed and taken away by the tsunami attacks. As the owner expected that it was not necessary to raise land level of his property much, Onoken's property was expected to be edge of land raising area, the owner started to repair his house and shop by himself in June 2012. His doze, however, also could be repaired together with them, but it was really hard to find and hire skilled plasterer for this work. Fortunately, the author found him in Iwate Prefecture side. He finished to apply first layer within 2012, and will be followed by lifting up and new foundation work in 2013 (Fig. 15).

\subsection{Kakuboshi and Otokoyama Brewery Shop}

Basically, the disappearing lower floors might be constructed by $\mathrm{RC}$ or steel and topped by the existing floor. According to the Japanese Building Code, ${ }^{2}$ mixed structure is not allowed except some cases. As these properties were subject to land raising and reallocation, the damaged shops were maintained on the site after some protection work was made (Figs. 16 and 17).

\subsection{Takeyama Rice Shop}

The front side land sunk $20 \mathrm{~cm}$ and so new foundation must be given. Although, front street may be widened, and the house and dozo will be set back $1 \mathrm{~m}$ or $2 \mathrm{~m}$, there is no space in back yard (Fig. 18).

\subsection{Chida's House, Shop and Dozos}

We limited scope of our restoration project to the

\footnotetext{
${ }^{2}$ The Building Code (Kenchiku Kijun-Ho), enacted in 1950,
} last revised in March 2014. damaged national listed heritage, and got grant only for them from the foundations in May 2012. Chida's House and Shop, however, were built after the 1929 Fire, and the dozo has existed before that. They had historical value to be as the national listed heritage, and have regarded as symbolical buildings for Kesennuma port-town by a famous graphical magazine in 1996 (Fig. 19). As a large number of people also regretted that the properties would be demolished, the author met him at his damaged house, and asked him not to give up these properties at the end of August 2012. A foundation fortunately showed interest to the properties, and assured to give us fund for the repair in February 2013. The tsunami attacks broke doors, windows and walls, and damaged the whole interior. As the lot is subject to the land raising, the buildings need to be raised tens centimeters high (Fig. 20).

As we expected that the tsunami-free town redevelopment scheme might be concluded by the authority and community council within 1 year, we divided work process into three years and three phases: emergency work, building of new floors, and repair/restoration work (Table 1).

Although the total fund to be granted by several foundations was lesser than our expectation/estimation, we had to start work, giving temporary and emergency works to the damaged heritage buildings so that they do not deteriorate by wind and rain. The fund is usually a grant-in-aid, and

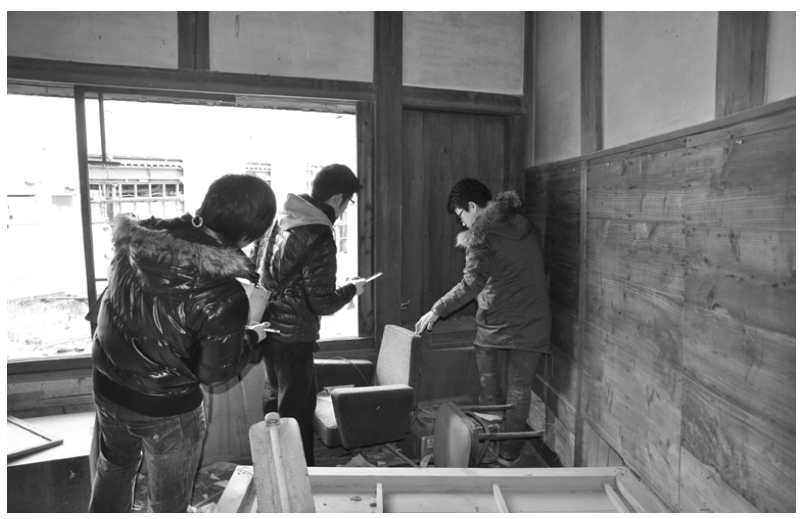

Fig. 14 Scene of measuring by students at Kakuboshi Shop. 

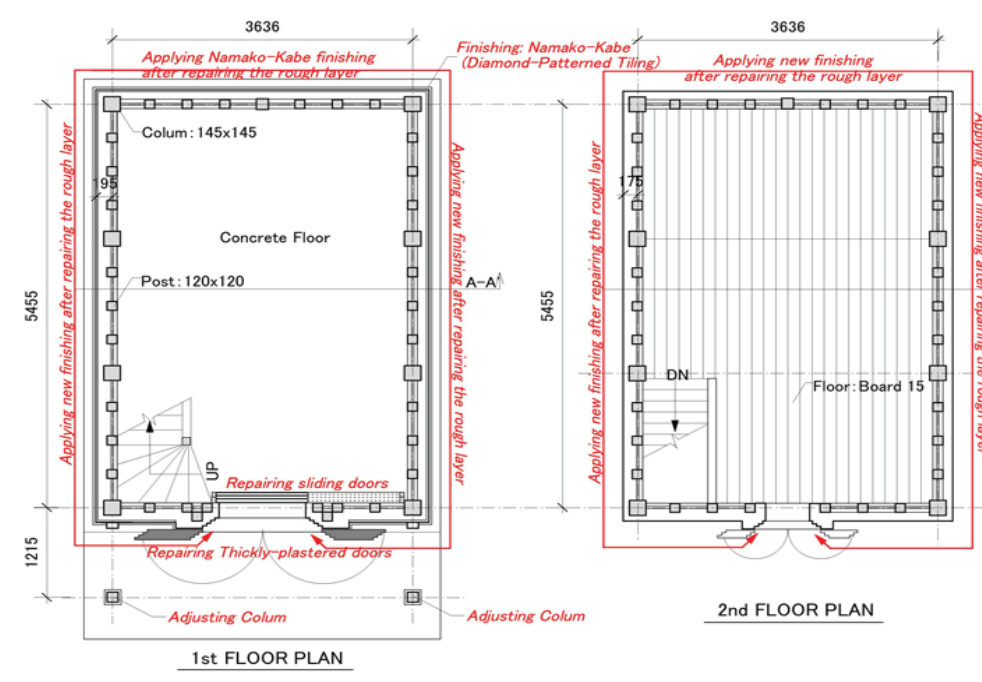

2nd FLOOR PLAN

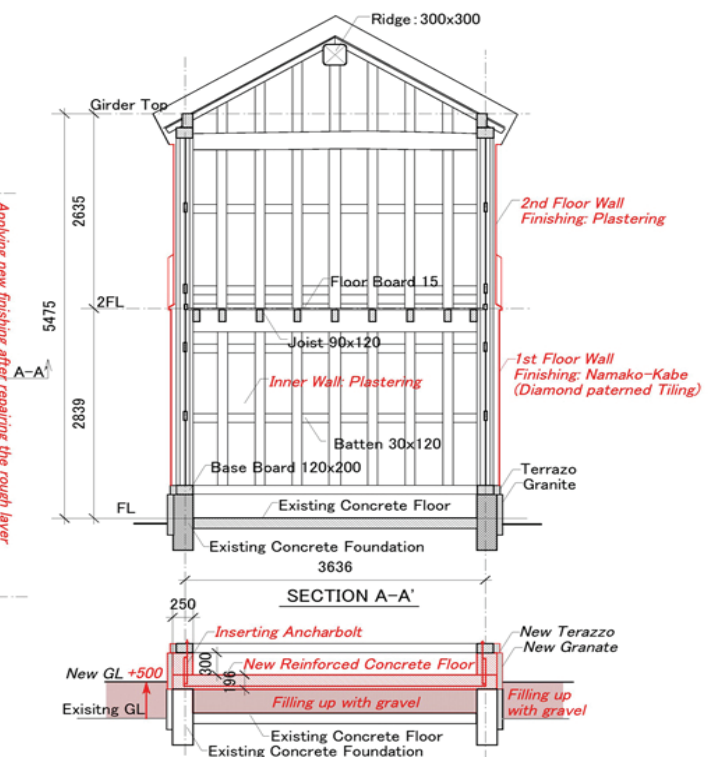

PLAN OF NEW FOUNDATION COPPING WITH LAND RECLAMATION

Fig. 15 Restoration plan for Onoken's dozo (units in mm).

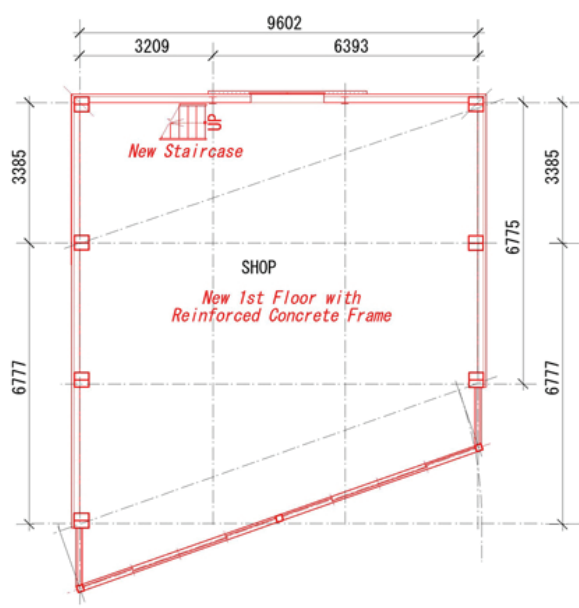

1st FLOOR PLAN: Reconstruction

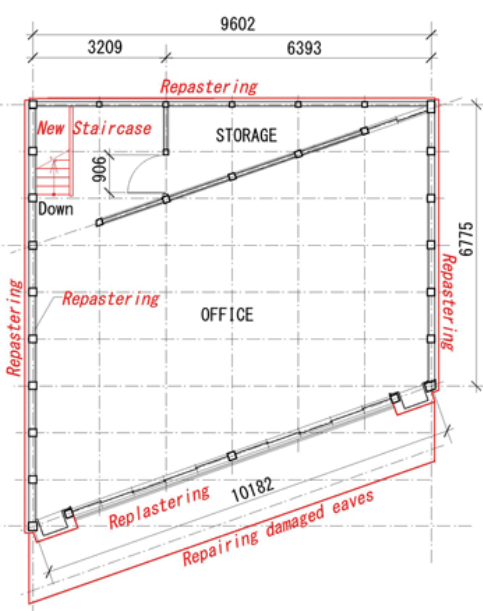

2nd FLOOR PLAN: Restoration

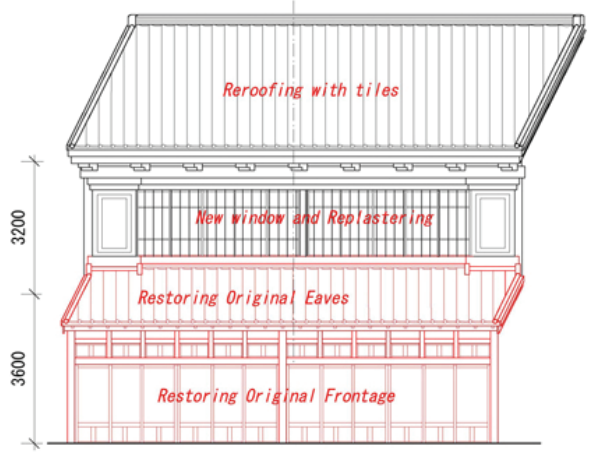

SOUTH FACADE

Fig. 16 Restoration plan for Kakuboshi Shop (units in mm).

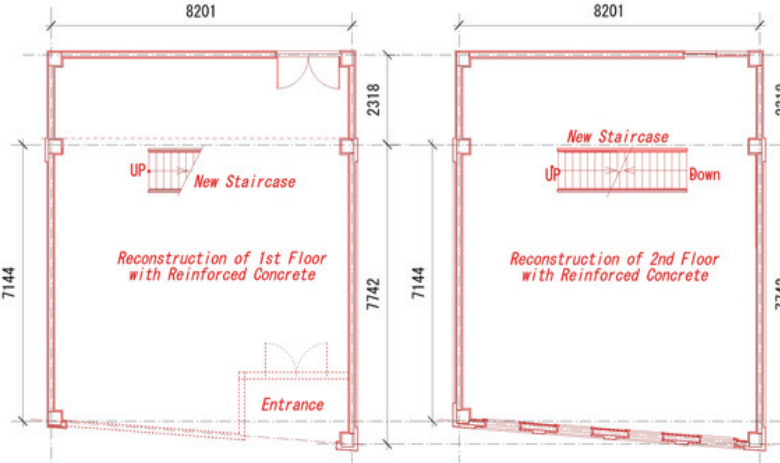

1st FLOOR PLAN: Reconstruction

2nd FLOOR PLAN: Reconstruction

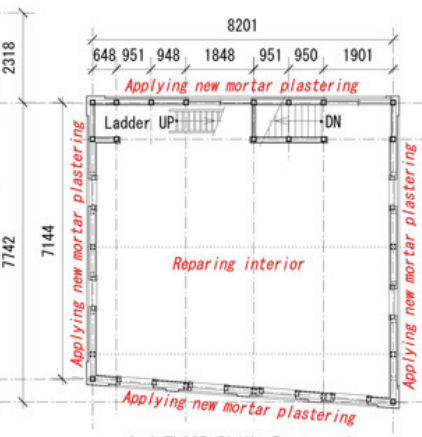

3rd FLOOR PLAN: Restoration

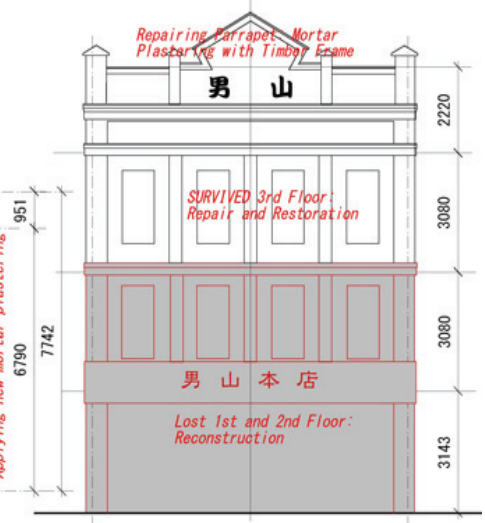

FRONT ELEVATION

Fig. 17 Restoration plan for Otokomaya Shop (units in $\mathbf{m m}$ ). 


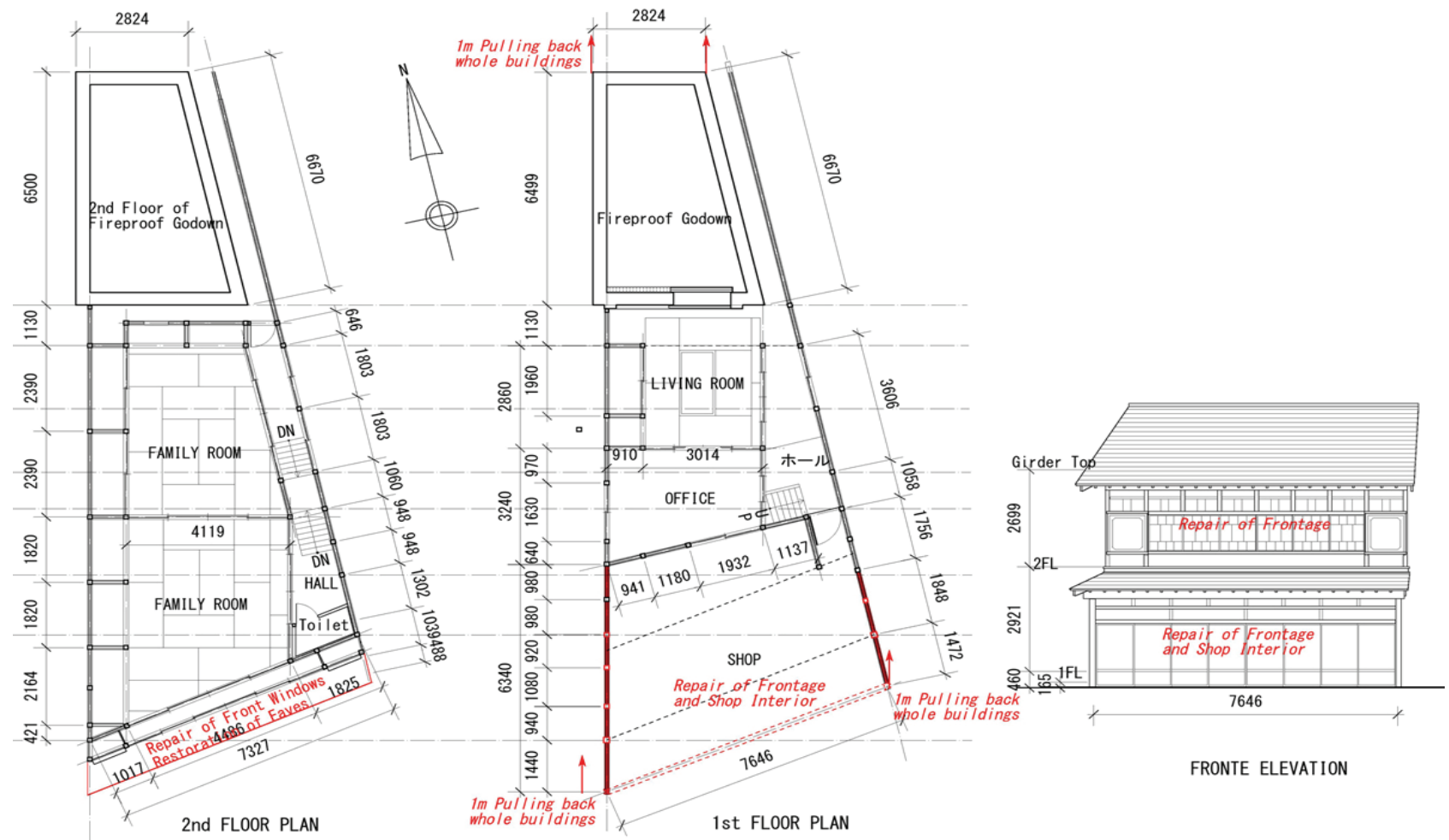

Fig. 18 Restoration plan for Takeyama Rice Shop (units in mm).

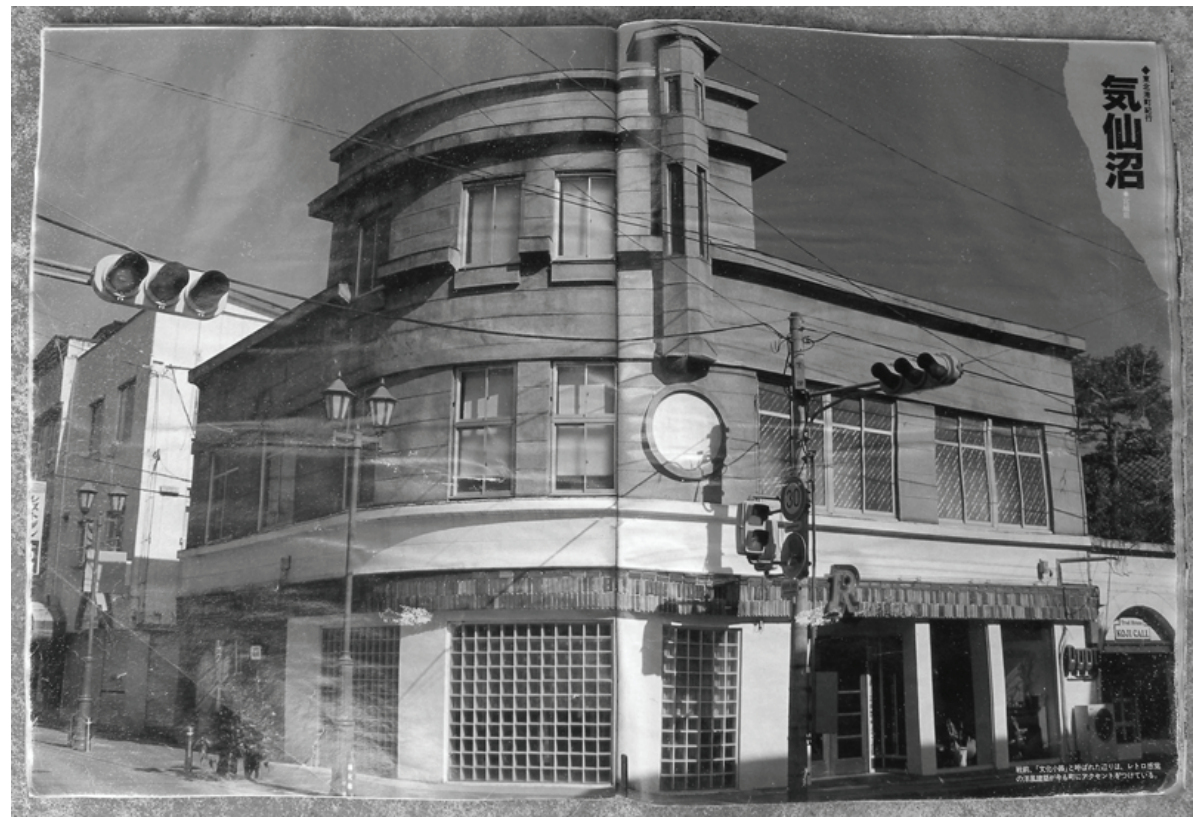

Fig. 19 Chida's Shop and house in Asahi Graphic, May 1996.

does not cover entire cost, and so owner may bear some part of cost by himself or have to find another fund. Actually, most of heritage owners did not afford to pay some money and spend his time for restoration of their properties. Every contractor was commissioned too many works during this building boom of post-disaster period, and it was so hard to find proper contractor for our work.

\section{Work Progress}

After the vertically surfacing breakwater based town redevelopment idea was rejected in early 2012 , 


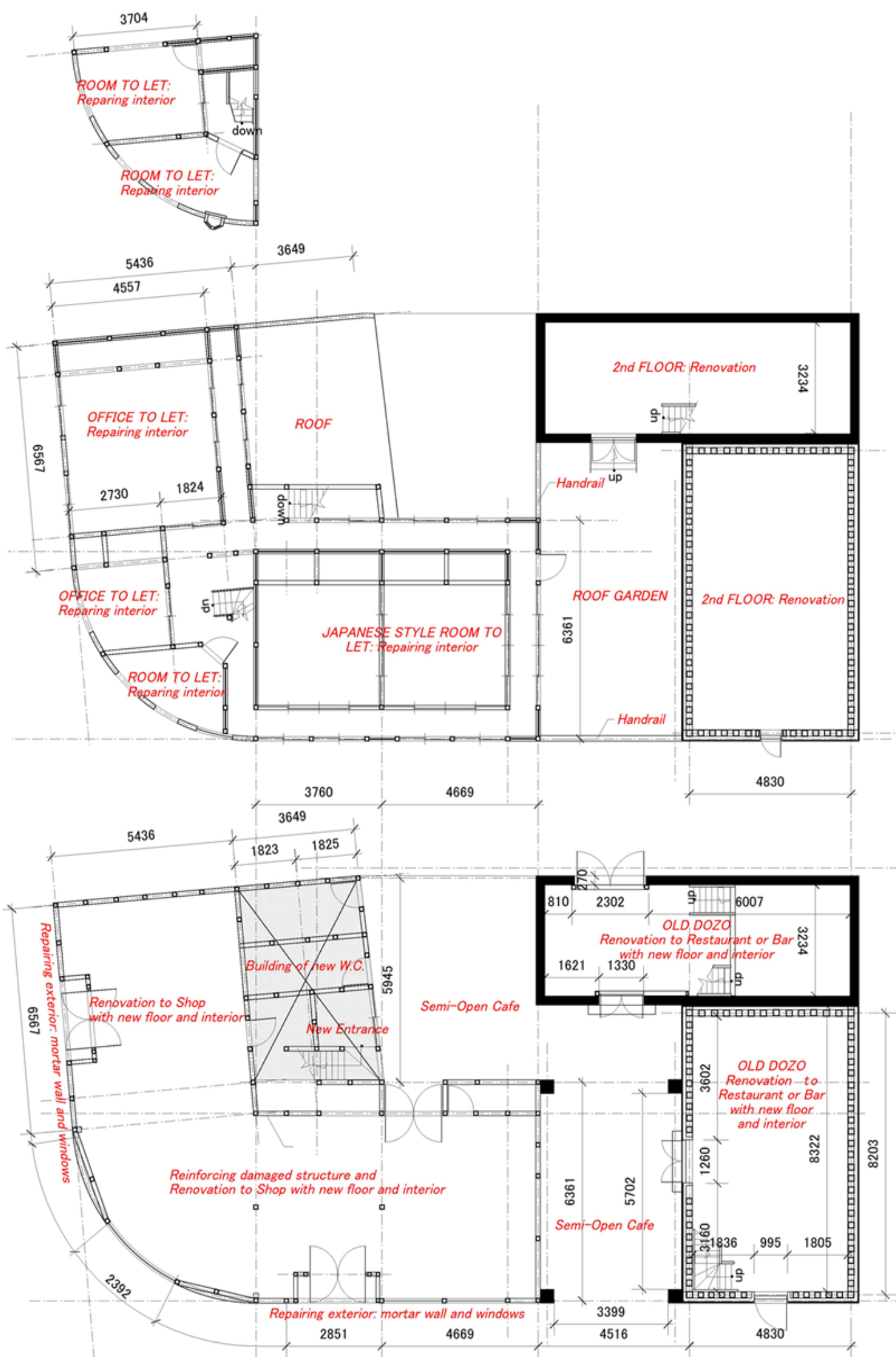

Fig. 20 Repair and renovation plan for Chida's (units in mm). 
Table 1 Expected schedule of restoration work.

\begin{tabular}{|c|c|c|c|c|c|c|c|}
\hline & & $\begin{array}{l}\text { Kakuboshi Brewery } \\
\text { Shop }\end{array}$ & \begin{tabular}{|l} 
Otokoyama \\
Brewery Head \\
Office
\end{tabular} & $\begin{array}{l}\text { Takeyama Rice } \\
\text { Shop }\end{array}$ & $\begin{array}{l}\text { Onoken } \\
\text { Fishery's Dozo }\end{array}$ & $\begin{array}{l}\text { Sasaki-Sanjido } \\
\text { Pottery Shop }\end{array}$ & $\begin{array}{l}\text { Chida's House, } \\
\text { Shop, Dozos }\end{array}$ \\
\hline \multirow{6}{*}{ ن } & $\begin{array}{l}\begin{array}{l}\text { Heritage } \\
\text { category }\end{array} \\
\end{array}$ & $\begin{array}{l}\text { National listed } \\
\text { heritage }\end{array}$ & $\begin{array}{l}\text { National listed } \\
\text { heritage }\end{array}$ & $\begin{array}{l}\text { National listed } \\
\text { heritage }\end{array}$ & $\begin{array}{l}\text { National listed } \\
\text { heritage }\end{array}$ & $\begin{array}{l}\text { National listed } \\
\text { heritage }\end{array}$ & $\begin{array}{l}\text { National listed } \\
\text { heritage }\end{array}$ \\
\hline & Structure & Timber frame & Timber frame & Timber frame & Timber frame & Timber frame & Timber frame \\
\hline & Exterior & Reinforced mortar & Reinforced mortar & Clay wall & Thick clay & Thick clay & $\begin{array}{l}\text { Reinforced } \\
\text { mortar }\end{array}$ \\
\hline & \begin{tabular}{|l|}
$\begin{array}{l}\text { Constructed } \\
\text { year }\end{array}$ \\
\end{tabular} & 1931 & 1930 & 1930 & 1946 & 1920 & 1930 \\
\hline & Damage & $\begin{array}{l}\text { 1st floor taken } \\
\text { away, 2nd floor } \\
\text { survived }\end{array}$ & $\begin{array}{l}\text { 1st floor taken } \\
\text { away, 2nd floor } \\
\text { survived }\end{array}$ & $\begin{array}{l}\text { Shop-front taken } \\
\text { away }\end{array}$ & $\begin{array}{l}\text { Thick clay } \\
\text { heavily broken }\end{array}$ & $\begin{array}{l}\text { Thick clay } \\
\text { cracked }\end{array}$ & $\begin{array}{l}\text { Reinforced } \\
\text { mortar, cracked, } \\
\text { etc. }\end{array}$ \\
\hline & Location & Minami-machi & Sakana-machi & Sakana-machi & Minami-machi & Minami-machi & Minami-machi \\
\hline \multirow{4}{*}{ 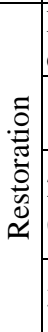 } & \begin{tabular}{|l|}
$\begin{array}{l}\text { Infrastructure } \\
\text { development }\end{array}$ \\
\end{tabular} & $\begin{array}{l}\text { Land raising, land } \\
\text { readjustment }\end{array}$ & \begin{tabular}{|l|} 
Land raising, land \\
readjustment
\end{tabular} & Street widening & Land raising & None & None \\
\hline & 1st year (2012) & $\begin{array}{l}\text { Emergency } \\
\text { protection work }\end{array}$ & $\begin{array}{l}\text { Emergency } \\
\text { protection work }\end{array}$ & $\begin{array}{l}\text { Emergency } \\
\text { protection work }\end{array}$ & Repair work & Repair work & None \\
\hline & $\begin{array}{|ll|}\text { 2nd } & \text { year } \\
(2013) & \\
\end{array}$ & $\begin{array}{l}\text { Restoration plan, } \\
\text { construction of } \\
\text { lower structure }\end{array}$ & $\begin{array}{l}\text { Restoration plan, } \\
\text { construction of } \\
\text { lower structure }\end{array}$ & $\begin{array}{l}\text { Lifting up, } \\
\text { restoration of } \\
\text { shopfront }\end{array}$ & Repair work & None & $\begin{array}{l}\text { Building plan } \\
\text { and repair work }\end{array}$ \\
\hline & 3rd year (2014) & $\begin{array}{l}\text { Repair of upper } \\
\text { floor, finishing }\end{array}$ & $\begin{array}{l}\text { Repair of upper } \\
\text { floor, finishing }\end{array}$ & None & None & None & None \\
\hline
\end{tabular}

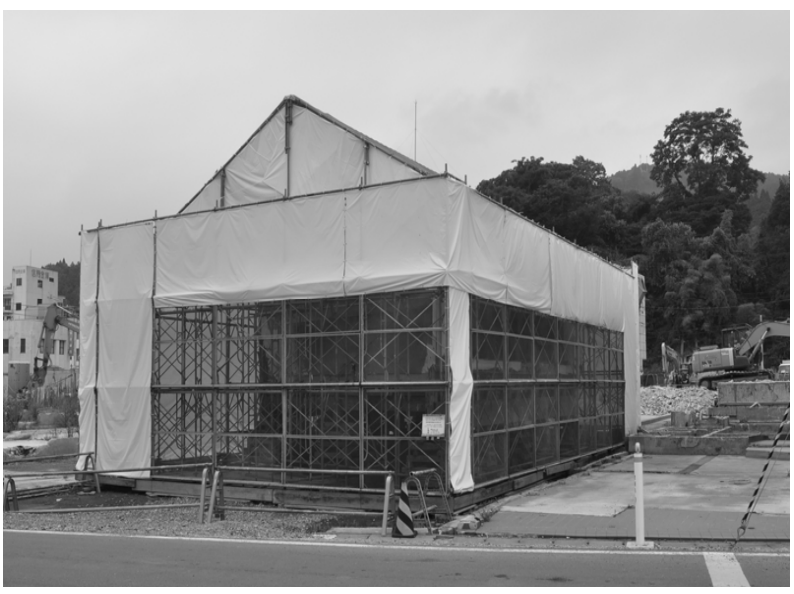

Fig. 21 Shelter for damaged Kakuboshi Shop.

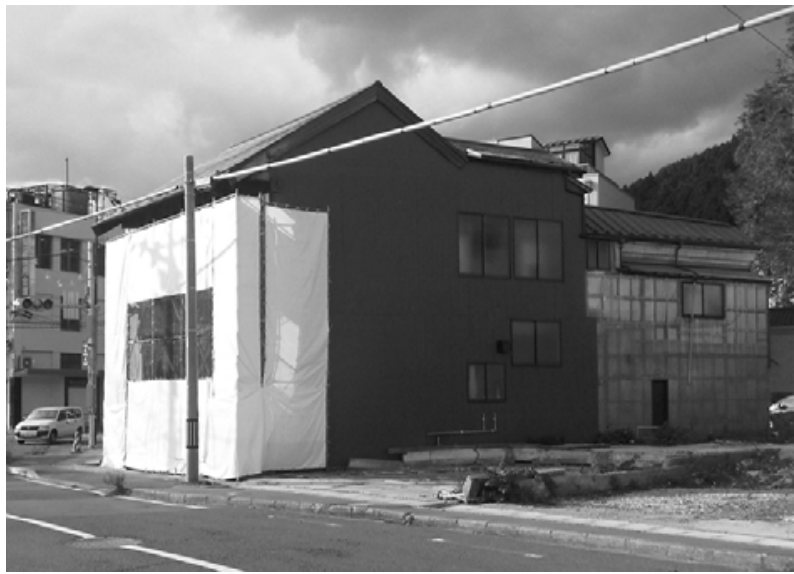

Fig. 22 Support and covering for Takeyama Rice Shop.

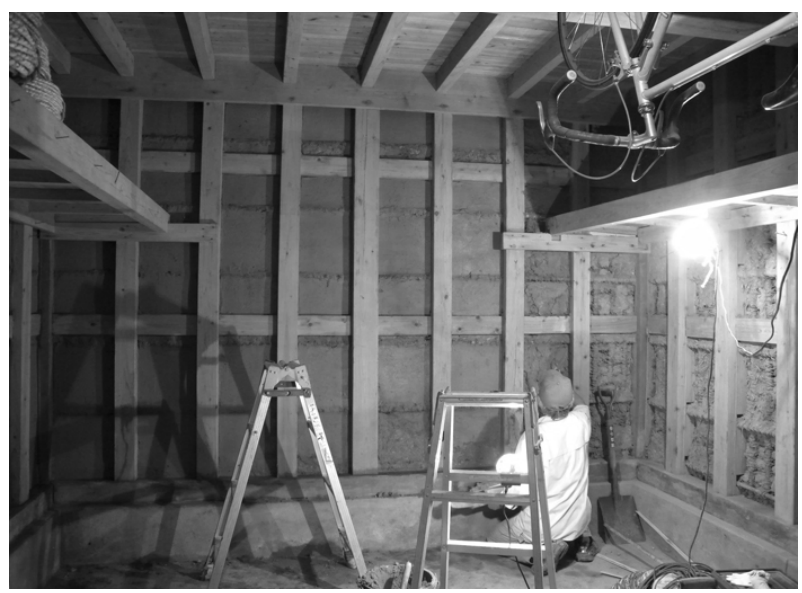

Fig. 23 Applying new rough layer to damaged Onoken's dozo.

the authority started to draft the town redevelopment plan by surrounding tall breakwater and land raisings, and discussed it with the community council. Land would be readjusted and reallocated according to the plan and agreement. As we assumed that they needed several months or a year until they conclude the plan, we got started on our restoration project by protection works: shelter for Kakuboshi (Fig. 21) and Otokoyama, and stable support for Takeyama (Fig. 22). The author drew the work plans, and started looking for builders in May 2012. It was just 1 year 


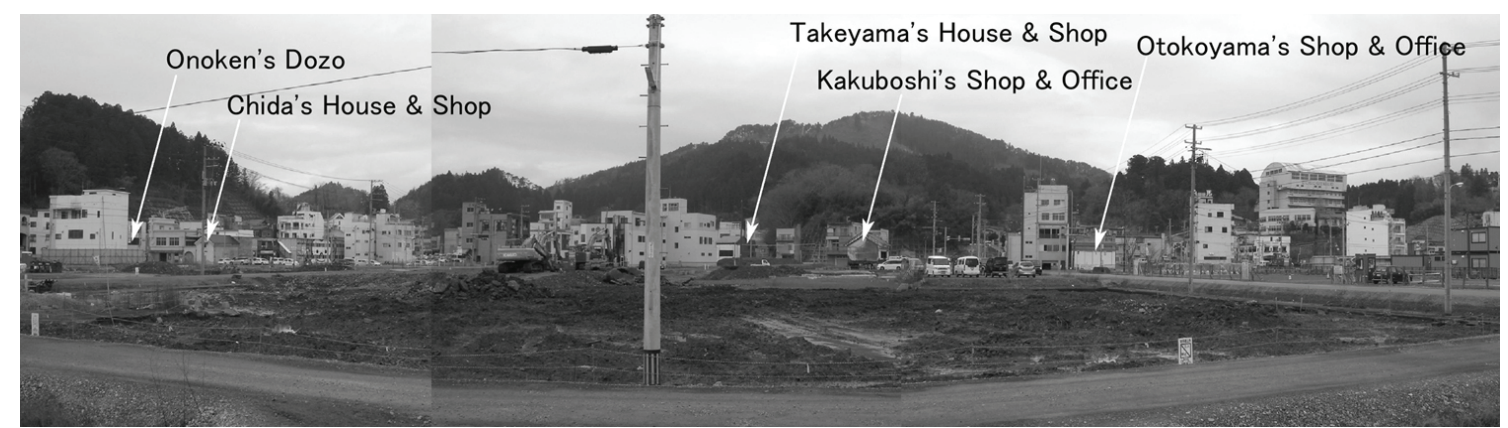

Fig. 24 A scene of the Naiwan on January 23 2014, waiting for redevelopment.

after the disaster, every contractor was too busy and confused to commission our minor works. We asked several contractors and finally we got it.

For the Onoken's dozo, we could start substantial restoration work by removing damaged clay away and applying rough layer on new bamboo lath (Fig. 23). But it was also hard to find experienced plasterer nearby. As our motto was "local heritage is hopefully to be maintained and repaired by local resources," we got him after a month searching at Iwate Prefecture.

\section{Conclusions}

As soon as we got started on protection work, people gathered at site to watch the work saying: "Oh! The damaged building is recovering, we can recover." We are very confident that our projects will gain people's hope for recovery, and that they will be the starting point of town redevelopment connecting past and future of Kesennuma. A community around Kakuboshi Shop stepped forward for redevelopment drawing physical planning of each new building employing an architect.

We started the restoration projects, and just entered the gate. One of the big problems is fund, as we did not expect owner's burden, but granted from the foundations. The foundations assured us of giving us full support until the end. But, it is hard to hire contractors and architects for each project unless we have enough funds in hand. Cost and price in the disaster-stricken area are getting higher. The second problem is the lack of office staff for the KFK who can take care of communication, information/data collection, accounting, some technical matters, etc.

In the end of 2013, the Agency of Cultural Affairs organized a series of symposiums to rouse public concern to various cultural restoration works inviting the parties and individuals concerned at Tokyo and Sendai. The World Monuments Fund, one of our main sponsors suggested us to adopt long-term view in two ways [7]:

(1) recovery efforts from major natural disasters which can take years or decades to create;

(2) creating responses that can have long-term impact and benefit for the future.

We first expected that we could complete it within three years, but now we have to reconsider it in long-term view. Once our historical built environment was damaged by tremendous disasters together with economic base, we need long-term consideration and support for the restoration as the Kesennuma case tells (Fig. 24). The Heritage Restoration Committee just completed two restoration-works: Onoken's Dozo and Sanjodo Potery Shop, and will carry out effort for more heritage buildings after the land readjustment scheme was settled down.

\section{References}

[1] Compiling Committee of Kesennuma Official City History. 1986. Kesennuma Official City History. Vol. 1 Nature. Kesennuma: Compiling Committee of Kesennuma Official City History.

[2] Reconstruction Agency. 2011. Guideline for Restoration from the 2011 Eastern Japan Earthquake. Japan: Reconstruction Agency.

[3] Compiling Committee of Kesennuma Official City 
History. 1990. Kesennuma Official City History. Vol. II Medieval Period. Kesennuma: Compiling Committee of Kesennuma Official City History.

[4] Ministry of National Land and Transportation. 2012. "Guidance for Townscape and Spatial Management in Earthquake Recovery Redevelopment Planning.” Ministry of National Land and Transportation. Accessed April 1, 2012. http://www.mlit.go.jp/common/000217102.pdf.

[5] City of Kesennuma. 2013. "Result of the Competition of Redevelopment Idea Competition for the Naiwan Area." City of Kesennuma. Accessed October 1, 2013. http://www.city.kesennuma.lg.jp/www/contents/133552
5945048/.

[6] Ministry of the National Land and Transportation. 2012. "Guideline for Earthquake Recovery Redevelopment Planning Feathering Historical-Cultural Heritage." Ministry of the National Land and Transportation. Accessed April 1, 2012. http://www.mlit.go.jp/ common/000221200.pdf.

[7] Ng, H. T. 2012. "One Year after the Japan Earthquake: A Journey, Part III and IV.” WMF (World Monuments Fund) Journal. Accessed December 22, 2013. http://www.wmf.org/journal/one-year-after-japan-earthqu ake-journey-part-iv. 